Reprod. Nutr. Dévelop., 1984, 24 (1), 45-51.

\title{
The effects of psychosomatic stress at the end of pregnancy on maternal and fetal plasma cortisol levels and liver glycogen in guinea-pigs
}

\author{
Pascale DAUPRAT, G. MONIN (*), M. DALLE, P. DELOST (1) \\ Laboratoire de Physiologie animale et ERA CNRS d'Endocrinologie du Développement, \\ Université de Clermont-Ferrand, B.P. 45, 63170 Aubière, France. \\ (*) Station de Recherches sur la Viande, I.N.R.A., Theix, 63122 Ceyrat, France.
}

Summary. Plasma cortisol and liver glycogen were measured in the mother, fetus and newborn of guinea-pig after a stress on days 60 and 67 of gestation (parturition occurring on day 68); at those times, the animals were held for $3 \mathrm{~h}$ in the dark and subjected to a flash of $75 \mathrm{~J}$ intensity every $10 \mathrm{sec}$. In comparison with the controls, stress increased plasma cortisol in both mothers and fetuses. While it decreased maternal liver glycogen on day 60 , it increased fetal liver glycogen at the same stage. Glycemia decreased in mothers after stress, although at delivery females previously stressed on day 60 showed hyperglycemia.

\section{Introduction.}

Fetal liver glycogen deposition is carried out under hormonal control in mammalian species (Shelley, 1961 ; Lipovac et al., 1973) ; fetal hypophysis as well as fetal adrenal glands are necessary for glycogenesis (Jost and Jacquot, 1954 ; Jost, 1966 ; Barnes et al., 1977).

An increase in plasma cortisol levels after stress has been demonstrated in pregnant and fetal guinea-pigs before parturition. The fact that maternal levels remain higher than the fetal ones suggests a transfer of this hormone across the placenta of the mother to the fetus.

Measurements of adrenal secretion rates in acute experiments (Dalle and Delost, 1979) have shown that the maternal adrenals are the principal source of the cortisol found in both the maternal and the fetal pools.

In liver explants of rat fetus in vitro, cortisol induces an increase in the total amount of glycogen (Coufalik and Monder, 1981). The injection of this hormone induces the same phenomenon in rat (Dorsey and Munck, 1962).

(1) To whom reprint requests should be addressed. 
Dalle and Delost (1979) have demonstrated in the guinea-pig that about $90 \%$ of the fetal cortisolemia is of maternal origin at the end of gestation. Since stress increases maternal plasma cortisol sharply just before parturition, the present study was undertaken to evaluate the influence of an acute physiological elevation of plasma cortisol on glycogen storage in the mother, fetus and newborn. For this purpose, female guinea-pigs were subjected to a stress during the last days of gestation.

\section{Material and methods.}

1. Animals. - Female guinea-pigs (Dunkin-Hartley strain; length of gestation $68 \pm 1$ days) were caged for $24 \mathrm{~h}$ with a male at oestrus time when the vagina was entirely open. They were given water and complete food (UAR pellets) every day at $8 \mathrm{a} . \mathrm{m}$. On day 60 or 67 of gestation, these females were subjected to a psychosomatic stress : they were held in a dark room in front of an intermittent luminous flash (period : $10 \mathrm{sec}$; intensity : $75 \mathrm{~J}$ ) for $3 \mathrm{~h}$ from $9 \mathrm{a} . \mathrm{m}$. to 12. After stress, one-half of the animals were killed immediately and the other half were allowed to rest until delivery which occurred on day 68 or 69 in the controls as well as in the stressed dams. Within the first $6 \mathrm{~h}$ after delivery, females and newborns as well as fetuses were killed by decapitation. Each stage, which included 6 females and 18-23 fetuses, was compared with a control group. The blood of decapitated mothers, fetuses and newborns, taken from the neck, was sampled on heparin and centrifuged and the plasma immediately stored at $-20^{\circ} \mathrm{C}$. Immediately after killing, the livers were weighed and frozen at

$-20^{\circ} \mathrm{C}$. Nine nonpregnant female guinea-pigs were sacrificed to obtain control values of plasma cortisol.

2. Cortisol estimation. - The plasma cortisol of mothers, fetuses and newborns was determined according to the competitive protein binding procedure of Murphy (1967), modified by Dalle and Delost (1976). Plasma cortisol levels were expressed in $\mu \mathrm{mol} / \mathrm{l}$.

3. Glycogen estimation. - Hepatic glycogen was evaluated according to the enzymatic procedure of Darlymple and Hamm (1973), modified by Gire (1976). The results were given in $\mu \mathrm{mol} / \mathrm{g}$ of liver.

4. Plasma glucose. - Plasma glucose was determined according to an enzymatic procedure using glucose dehydrogenase (Banauch et al., 1975). The results were given in $\mathrm{g} / \mathrm{l}$.

The means + SEM have been given for all parameters. Their statistical significance was determined by Student's t-test.

\section{Results.}

1. Plasma cortiso/ levels in basal conditions and after stress.

a) Pregnant females (fig. 1). - In the coritrol group, plasma cortisol levels reached very high values on day 60 of gestation, i.e. about 20 times higher than 
those of nonpregnant female guinea-pigs. These values remained at a steady level until day 67 and were not modified by delivery.

On day 60 , stress provoked a significant rise in plasma cortisol levels (156\%; $P<0.001)$. On day 67, this rise was less $(62 \% ; P<0.001)$.

Plasma cortisol levels of mothers after delivery were not changed by prepartum stress.

b) Fetuses and newborns (fig. 2). - On day 60, the levels of fetal plasma cortisol in the control group were similar to those found in nonpregnant adults. Between day 60 and birth, plasma cortisol increased markedly $1726 \%$; $P<0.001)$.

Maternal stress increased fetal plasma cortisol levels by $650 \%(P<0.001)$ on day 60 and by $120 \%(P<0.001)$ on day 67 .

At birth, no significant change was induced by prenatal stress on day 60 , but a decrease of $26 \%(P<0.01)$ occurred when the dams were stressed on day 67 .

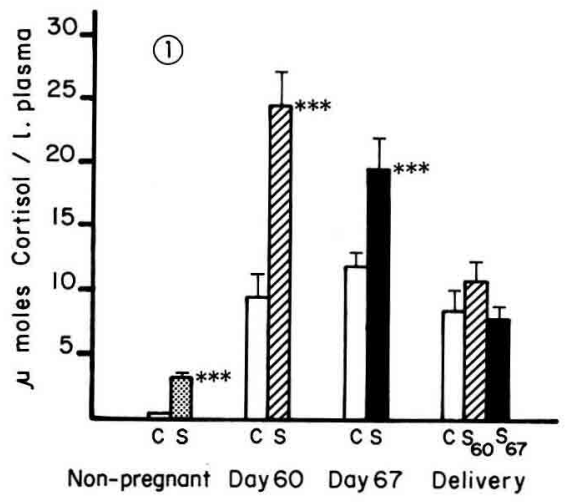

FIG. 1. - Plasma cortisol leve/s in female guinea pigs on days 60 or 67 of gestation or at delivery ; stress was applied on day 60 or 67 of gestation. Comparison with non-pregnant females.

Controls : $\square$; non-pregnant stressed females : ; females stressed on day 60 : $\mathbb{Q} ;$ females stressed on day 67: (***P $P<0.001)$

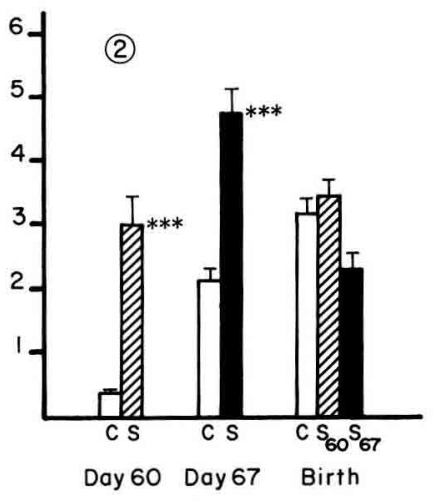

FIG. 2. - Plasma cortisol levels in fetal or newborn guinea-pigs of dams stressed on day 60 or 67 of gestation; measurements were taken immediately after the stress or at birth.

Controls : $\square$; fetuses of females stressed on day 60 : f fetuses of females stressed on day 67: $\square .1^{* * *} P<0.001 ;{ }^{* *}$ $P<0.01$ ).

\section{Hepatic glycogen.}

a) Pregnant females (fig. 3). - During the last week of gestation, hepatic glycogen increased in the control group by $88 \%(P<0.001)$ and was not modified by delivery.

After stress on day 60 , glycogen stores fell by $67 \%(P<0.001)$. On day 67 , stress did not produce any change in hepatic glycogen stores. Furthermore, it had no long-term effect since it did not modify hepatic glycogen at delivery. 
b) Fetuses and newborns (fig. 4). - Glycogen accumulation in the livers of fetuses was very high between days 60 and 67 of intra-uterine life $11200 \%$; $P<0.001$ ).

Maternal stress produced a fetal hepatic glycogen increase only on day 60 (210\% ; P $<0.001)$.

Prepartum maternal stress had no influence on hepatic glycogen stores of the pups at birth.

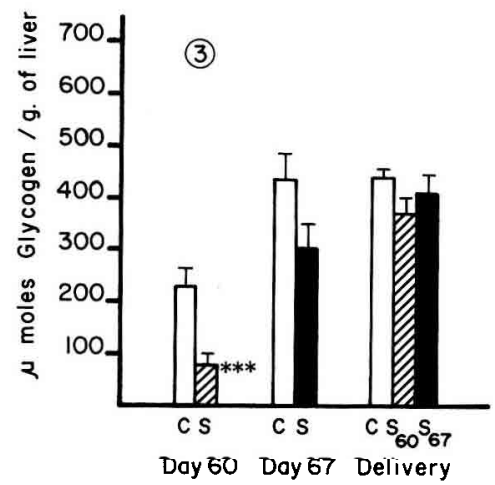

FIG. 3. - Liver glycogen in female guinea-pigs stressed at day 60 or 67 of gestation; measurements were taken immediately after the stress or at delivery (same symbols as

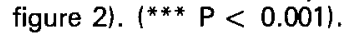

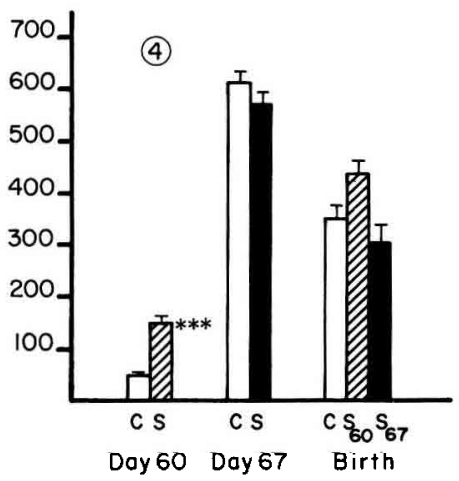

FIG. 4. - Liver g/ycogen in fetal and newborn guinea-pigs of dams stressed at day 60 or 67 of gestation; measurements were taken immediately after the stress or at birth (same symbols as figure 2). (*** $\mathrm{P}<0.001)$.

\section{Plasma g/ucose.}

a) Pregnant females (fig. 5). - Glycemia significantly increased in the control group at the time of delivery $(5 \% ; P<0.01)$.

Stress was followed by a slight hypoglycemia $110 \% ; P<0.05$ on day 60 and $5 \% ; P<0.01$ on day 67$)$.

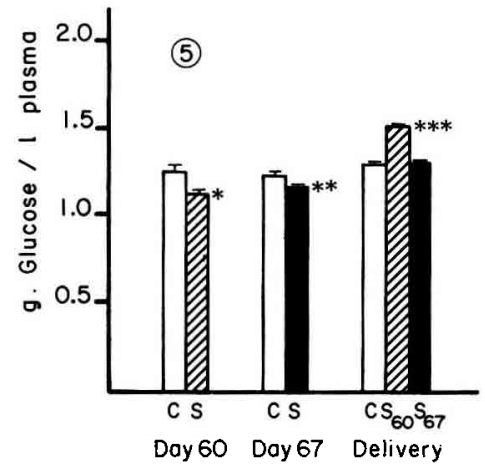

FIG. 5. - G/ycemia in female guinea-pigs stressed at day 60 or 67 of gestation; measurements were taken immediately after the stress or at delivery (same symbols as

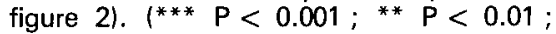
$* \mathrm{P}<0.051$.

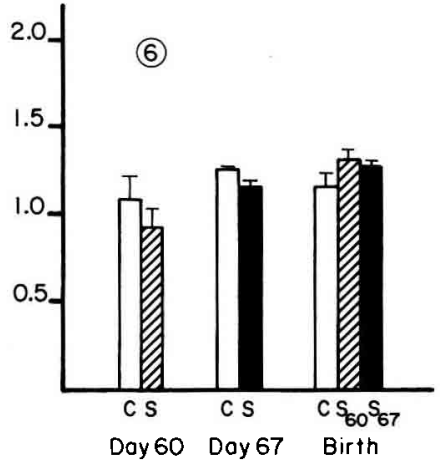

FIG. 6. - Glycemia in fetal and newborn guineapigs of dams stressed at day 60 or 67 of gestation ; measurements were taken immediately after the stress or at birth (same symbols as figure 2 ). 
After delivery animals which had been subjected to stress on day 60 showed hyperglycemia (16\%; $P<0.001)$.

b) Fetuses and newborns (fig. 6). - Basal fetal glycemia was similar to the maternal one $(1.1 \mathrm{~g} / \mathrm{l})$. Glycemia was not changed by either prepartum maternal stress or birth.

\section{Discussion.}

At the end of pregnancy and especially near term, the adrenal glands of the female guinea-pig are strongly stimulated (Dalle and Delost, 1976). However, stress induced a marked increase in plasma cortisol, demonstrating that the adrenals of the pregnant guinea-pig can be hyperstimulated as those of pregnant mouse (Barlow et al., 1975, 1976) or pregnant rat (Ward and Weiss, 1980). Hence, the high plasma cortisol levels observed during pregnancy do not block the hypothalamo-hypophyseal axis. In the guinea-pig, maternal stress increased plasma cortisol in mothers as well as in fetuses, and the absolute differences between the two pools remain stable due to increased transfer from mother to fetus (Dalle and Delost, 1976, 1979).

During stress, a release of adrenaline generally occurs (Frankenhaeuser, 1971). In guinea-pigs stressed on day 60 of pregnancy, a drop in liver glycogen was observed, probably as a consequence of glycogenolysis induced by catecholamines.

After stress, a slight hypoglycemia was observed simultaneously with the cortisol increase. This could be the result of the stimulation of insulin release by corticosteroid increase (Perley and Kipnis, 1966) and/or of the permissive effect of corticosteroids on the action of insulin on tissue receptors.

No changes in maternal liver glycogen were observed on day 67 of pregnancy. In fact, at this stage of pregnancy, the mother seemed to be under permanent stress due to prepartum labor. Indeed, the induction of parturition had begun since about $24 \mathrm{~h}$ (Illingworth et al., 1974). In this strain, prepartum labor lasts at least 2 day's (Dalle, unpublished observations), and it is possible that adrenaline would no longer be secreted, as in the case of recurring and iterative stress (Mikulaj et al., 1974 ; Kvetnansky et al., 1977 ; Burchfield, 1979). The decrease in the intensity of adrenal response to stress at this stage of pregnancy seems logical ; in fact, the efficiency of adrenal response to stress has often been demonstrated to be inversely related to the intensity of the stimulation before stress, as shown in guinea-pig by Viru and Akke (1969).

Maternal stress induced an increase in plasma cortisol in fetuses. Fetal liver glycogen, which is usually very low at 60 days, was strongly increased after stress. The importance of this well-known glycogenic effect of glucocorticoids (Dorsey and Munck, 1962) could indicate that specific membrane receptors for cortisol (whose presence was shown in the last stage of intra-uterine life by Giannopoulos, 1975) are functional on day 60 in guinea-pig fetuses. Moreover, the fetal liver in this species would already possess mature enzymatic equipment for glycogen synthesis. 
In the mother, the glycogenolytic effect of adrenaline dominated the glycogenic effect of corticosteroids; on the contrary, in the fetus, the considerable increase of liver glycogen content after maternal stress indicates that catecholamines had no significant effect on fetal liver glycogen, whether due to the fact that stress did not induce adrenaline release in the fetus or that adrenaline did not cross the placenta. Indeed, it has been demonstrated in several species that the amounts of catecholamines which might cross the placenta are negligible and immediately catabolized (for a review, see Anton, 1979).

At the end of pregnancy, blood glucose levels are similar and tend to become identical near term in guinea-pig mothers and fetuses (Hard et al., 1944 ; Dalle and Delost, 1976). At delivery, female guinea-pigs stressed on day 60 demonstrated a slight hyperglycemia $(+15 \%)$. Glucocorticoid excess, produced by stress, may induce a long-term diabetogenic effect which could be due to a decrease of either the number or the sensitivity of insulin receptors (Olefsky et al., 1975 ; Kahn et al., 1978). A stress applied near term to the pregnant female seemed to change neither glycogenesis intensity nor glycemia regulation in the newborn.

Reçu en mars 1983.

Accepté en septembre 1983.

Résumé. Effets d'un stress psychosomatique appliqué à la fin de la gestation sur les taux plasmatiques de cortisol et les teneurs hépatiques en glycogène de la mère et du fous chez le cobaye.

Les taux plasmatiques de cortisol et les teneurs hépatiques en glycogène ont été mesurés chez le cobaye (mère, fœetus et nouveau-né) après un stress appliqué aux $60^{\mathrm{e}}$ et $67^{\mathrm{e}}$ jours de gestation (la parturition se produisant le $68^{\mathrm{e}}$ jour). Le stress consistait dans le maintien à l'obscurité pendant $3 \mathrm{~h}$, avec déclenchement d'un éclair d'intensité $75 \mathrm{~J}$ toutes les 10 secondes. Par rapport aux témoins, le stress augmentait le cortisol plasmatique à la fois chez la mère et le foetus. Tandis qu'il diminuait le taux de glycogène hépatique chez la mère le $60^{\mathrm{e}}$ jour, il augmentait ce taux chez le fœtus. La glycémie diminuait chez la mère après le stress, cependant qu'à la mise-bas les femelles précédemment soumises au stress le $60^{\mathrm{e}}$ jour manifestaient une hyperglycémie.

\section{References}

ANTON A. H., 1979. Catecholamines during pregnancy and their effects on the fetus. Pediat. Adolesc. Endocr., 5, 110-125.

BANAUCH D., BRUMMER W., EBELING W., METZ H., RINDFREY H., LANG H., LEYBOLD K., RICK W., 1975. A glucose dehydrogenase for the determination of glucose concentrations in body fluids. Z. klin. Chem. klin. Biochem., 13, 101-107.

BARLOW S. M., MORRISON P. J., SULLIVAN F. M., 1975. Effects of acute and chronic stress on plasma corticosterone levels in the pregnant and nonpregnant mouse. J. Endocr., 66, 9399.

BARLOW S. M., QUYYUMI A. A., RAJARATNAM D. V., SULLIVAN F. M., 1976. Effects of stress and adrenocorticotropin administration on plasma corticosterone levels at different stages of pregnancy in mouse. Experientia, 32, 1480-1481.

BARNES R. J., FOWDEN A. L., SILVER M., COMLINE R. S., 1977. Liver glycogen concentrations in foetal lamb and pig. Ann. Rech. vét., 8, 374-378. 
BURCHFIELD S. R., 1979. Review article. The stress response : a new perspective. Psychosom. Med., 41, 661-672.

COUFALIK A. H., MONDER C., 1981. Stimulation of gluconeogenis by cortisol in fetal rat liver organ culture. Endocrinology, 108, 1132-1137.

DALLE M., DELOST P., 1976. Plasma and adrenal cortisol concentrations in fetal, newborn and mother guinea-pigs during the perinatal period. J. Endocr., 70, 207-214.

DALLE M., DELOST P., 1979. Foetal-maternal production and transfer of cortisol during the last days of gestation in the guinea-pig. J. Endocr., 82, 43-51.

DARLYMPLE R. M., HAMM R., 1973. A method for the extraction of glycogen and metabolites from a single muscle sample. J. Food Tech., 8, 439-444.

DORSEY J. L., MUNCK A., 1962. Studies on the mode of action of glucocorticoids in rats : a comparison of the effects of cortisol and glucose on the formation of liver glycogen. Endocrinology, 71, 605-608.

FRANKENHAEUSER M., 1971. Behavior and circulating catecholamines. Brain Res., 31, $241-262$.

GIANNOPOULOS G., 1975. Ontogeny of glucocorticoid receptors in rat liver. J. biol. Chem., 250. 5847-5851.

GIRE P., 1976. Contribution à l'étude du déterminisme des viandes à coupe sombre chez le mouton : facteurs de mobilisation du glycogène musculaire pendant le stress de transport. Th. $3^{e}$ Cycle, Clermont-Ferrand, 147 pp.

HARD W. L., REYNOLDS O. E., WINBURY M., 1944. Carbohydrate, fat and moisture relationships in the pregnant, fetal and newborn guinea-pigs. J. exp. Zool., 96, 189-199.

ILLINGWORTH D. V., CHALLIS J. R. G., ACKLAND N., BURTON A. M., HEEP R. B., PERRY J. S., 1974. Parturition in the guinea-pig ; plasma levels of steroid hormones, steroid-binding proteins and oxytocin, and the effect of corticosteroids, prostaglandins and adrenocorticotrophin. J. Endocr., 63, 557-570.

JOST A., 1966. Problem of fetal endocrinology: the adrenal glands. Laurentian Conf., Recent Progr. Horm. Res., 22, 541-569.

JOST A., JACQUOT R., 1954. Recherches sur le contrôle hormonal de la charge en glycogène du foie foetal du Lapin et du Rat. C. R. Acad. Sci. Paris, 239, 98-100.

KAHN C. R., GOLDFINE I. D., NEVILLE D. M. Jr, DEMEYTS P., 1978. Alterations in insulin binding induced by changes in vivo in the levels of glucocorticoids and growth hormone. Endocrinology, 103, 1054-1066.

KVETNANSKY R., SUN C. L., TORDA T., KOPIN I. J., 1977. Plasma epinephrine and norepinephrine levels in stressed rats. Effect of adrenalectomy. Pharmacologist, 19, 241-249.

LIPOVAC K., MIKOVIC K., MILKOVIC S., 1973. Adrenocortical hormones and the deposition of liver glycogen in the rat fetus. Endocrinology, 92, 336-339.

MIKULAJ L., KVETNANSKY R., MURGAS K., 1974. Changes in adrenal response during intermittent and repeated stress. Rev. Czech. Med. 20, 162-178.

MURPHY B. E. P., 1967. Some studies of the protein binding of steroids and their application to the routine micro and ultramicro measurement of various steroids in body fluids by competitive protein binding radioassay. J. clin. Endocr. Met., 27, 973-990.

OLEFSKY J. M., JOHNSON J., LIU F., JEN P., REAVEN G. M., 1975. The effects of acute and chronic dexamethasone treatment on insulin binding to isolated rat hepatocytes and adipocytes. Metabolism, 24, 517-521.

PERLEY M., KIPNIS D. M. 1966. Effect of glucocorticoids on plasma insulin. N. Engl. J. Med., 274, 1237-1240.

SHELLEY H. J., 1961. Glycogen reserves and their changes at birth and in anoxia. Brit. Met. Bull., 17, 137-143.

VIRU A., AKKE M., 1969. Effects of muscular work on cortisol and corticosterone content in the blood and adrenals of guinea-pigs. Acta endocr., 62, 285-390.

WARD I. L., WEISS L., 1980. Maternal stress alters plasma testosterone in fetal male. Science, 207. 328-329. 